\title{
ISABEL DE BRAGANÇA: A HERDEIRA RELUTANTE DO IMPÉRIO TROPICAL
}

Marcelo Penna da Silva ${ }^{1}$

Resumo: O presente trabalho busca uma análise baseada na relutância da Princesa Imperial, sob uma óptica de sua obstinação em governar o Império em um Terceiro Reinado. Analisa-se os feitos realizados pela dita princesa em seus períodos de regência, bem como os problemas enfrentados, seja pelo embate de gênero ou pela não predileção de seu pai, Pedro II, em vê-la governar. Assim, acerca de metodologia de gabinete, o presente trabalho visa uma análise sociopolítica, articulada ao processo da imagem da princesa na política no Segundo Reinado, com reflexões diretas ao expoente da Lei Áurea, que modifica toda uma linha histórica brasileira.

Palavras-chave: Segundo Reinado, Isabel de Bragança, Brasil Império.

1 Graduando em Geografia/Universidade do Estado do Rio de Janeiro - UERJ, Brasil. E-mail: celo_penna2@hotmail.com. 